\title{
Asynchronous development of two Late Glacial lake basins near the Drwęca ice-marginal valley (N Poland)
}

\author{
Wojciech W. GAMRAT ${ }^{1,}$ *, Mirosław BŁASZKIEWICZ ${ }^{2}$, Leon ANDRZEJEWSKI ${ }^{1}$ and Iwona KRZEŚLAK ${ }^{1}$ \\ 1 Nicolaus Copernicus University, Department of Geomorphology and Paleogeography of the Quaternary, Lwowska 1, \\ 87-100, Toruń, Poland \\ 2 Institute of Geography and Spatial Organisation of the Polish Academy of Sciences, Department of Environmental Resources \\ and Geohazard, Kopernika 19, 87-100 Toruń, Poland
}

Gamrat, W.W., Błaszkiewicz, M., Andrzejewski, L., Krześlak, I., 2017. Asynchronous development of two Late Glacial lake basins near the Drwęca ice-marginal valley (N Poland). Geological Quarterly, 61 (2): 450-464, doi: 10.7306/gq.1348

\begin{abstract}
Lacustrine organic sediments were sampled at Gronowo (Chełmno Plateau) and Piotrkowo (Dobrzyń Plateau) located within a widespread system of subglacial channels separated by the large Drweca ice-marginal valley. They have been examined for their pollen, plant macro-remains and geochemistry, as well as radiocarbon-dated. The analyses have allowed reconstructing the evolution of the area and presenting an asynchronous appearance of two lakes. Before lake sedimentation, glaciolimnic sediments from the end of Plenivistulian, at the site of Piotrkowo, was dated. Lacustrine sedimentation started during the Allerød at Gronowo, and during the Preboreal at Piotrkowo. The different age of the two lakes is ascribed mainly to differences in the Late Glacial drainage conditions which directly affected the melting away of dead-ice blocks buried in the channels.
\end{abstract}

Key words: Palaeolakes, buried dead-ice, Plenivistulian, Late Glacial, Holocene, northern Poland.

\section{INTRODUCTION}

Lake depressions can be easily recognized in the morphology of areas covered by ice of the Last Glacial Maximum (LGM). Some of these areas still include lakes, but most of the lakes disappeared because the depressions have become completely filled with sediments and changed into peat bogs. In the past few years, sediments that had accumulated in such lake basins have been investigated by large interdisciplinary research groups. These focused particularly on the reconstruction of environmental and climatic changes during the last 15,000 years (Ralska-Jasiewiczowa et al., 1998; Błaszkiewicz, 2013; Słowiński et al., 2014), and provided several new data on the morphogenesis of the lake basins. While their Holocene evolution, especially in the context of hydrological changes, has been described relatively well, numerous questions concerning the Late Glacial evolution of these lake basins have still to be answered. This particularly holds for the processes involved in the basin formation, the beginning of lacustrine sedimentation, or the identification of earlier (glaciolimnic sediments) lake-generations.

It appears that these questions get more various answers with the increasing number of examined lake basins. Apart from the most common group of lakes, which developed in what might be in simple called the Bölling-Allerød complex, this is shown by studies of both the (older) pre-Allerød lake genera-

\footnotetext{
* Corresponding author, e-mail: wojgam@umk.pl
}

Received: April 27, 2016; accepted: September 30, 2016; first published online: March 8, 2017 tions and the (younger) lakes that developed at the beginning of the Holocene (e.g., Więckowski, 1993; Ralska-Jasiewiczowa, 1998; Niewiarowski, 2003; Błaszkiewicz, 2005; Kaiser et al., 2009; Gamrat et al., 2014). The different ages of the lakes can be explained satisfactorily only by the complexity of the melting away of buried dead-ice blocks. This is commonly accepted for lakes in postglacial areas, but published data about the time of melting and the role of this melting in the morphogenesis of lake basins vary significantly (Nitz, 1984; Pachur and Röper, 1987; Böse, 1995; Nitz et al., 1995; Marks, 1996; Kaiser, 2001; Błaszkiewicz, 2005, 2011a; Błaszkiewicz et al., 2015).

Studies presented in this contribution also indicate different times of the appearance of the lakes in the basins under study, which developed under different hydrogeological conditions within the same subglacial channel, although on opposite sides of a large ice-marginal valley (Fig. 1). This difference in the conditions provided a sound basis for a comparative analysis that aims at recognition of the reasons for the different ages of postglacial lakes, and at a thorough discussion of the issues related to the Late Glacial evolution of lake basins in areas that were covered by the last glaciation.

\section{STUDY AREA}

The study area is located at the contact zone between two postglacial landscape units, the Chełmno and Dobrzyń lakelands (Kot, 2015), which are separated by the lower Drwęca ice-marginal and river valley (Fig. 1). Their morphology, developed during the last late Vistulian stillstand of the ice sheet, is characterized by numerous subglacial channels. The channels can be easily recognized because they show various geomorphological features as well as different orientations with 


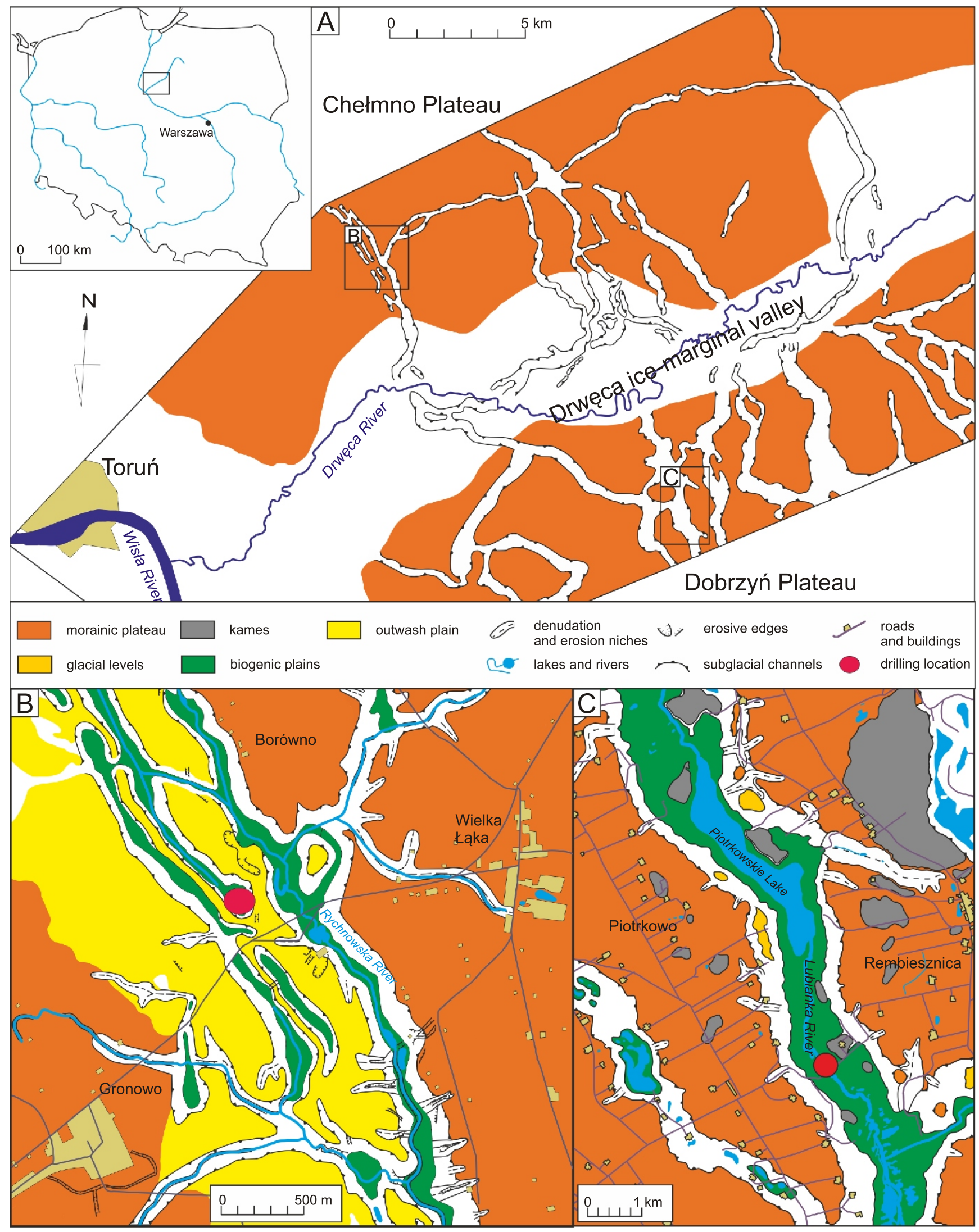

Fig. 1. Location of the study areas

A - Drwęca ice-marginal valley; B - schematic geomorphology of the Gronowo site; C - schematic geomorphology of the Piotrkowo site 
respect to the margin of the last ice sheet (Niewiarowski, 1959; Dzierżek, 2009). The forms are an important component of valley-lake systems within the area of Poland that was reached by last ice sheet (Andrzejewski, 1994; Błaszkiewicz, 1998, 2005).

Many aspects of subglacial channel morphogenesis have been explained and discussed already in numerous works, e.g. by Kozarski (1967), Pasierbski (1979), Galon (1983), Niewiarowski (1988, 1995a), Benn and Evans (1998), Molewski (1999), and Piotrowski (2014). The forms, showing various orientations and shapes, cut through morainic uplands, outwash plains and, in specific cases, ice-marginal and river valleys. Such intersections of subglacial channels with ice-marginal and river valleys provide opportunities for palaeogeographic interpretation of the complex processes that were involved in the formation of valley-lake systems, particularly with respect to their early stages (which followed immediately after the disappearance of the ice sheet) and their later phases (which were linked to gradual degradation of dead ice that was preserved in the deepest parts of the systems).

The two channels, in which the lake basins under study developed, belong to a joint system of connected channels incised into the Chełmno and Dobrzyń plateaus. They are separated from one another by the Drwęca ice-marginal and river valley (Niewiarowski, 1968). The northern area of the channel system, situated within the southern part of the Chełmno Plateau, is developed on an outwash plain. The channel follows oriented depressions in the Drwęca ice-marginal valley, such as the relatively deep and long basin of Okonin Lake (Błaszkiewicz and Kordowski, 2009). The channel subsequently extends on the Dobrzyń Plateau, where it is partly occupied by the Lubianka River and Piotrkowskie Lake. It shows clearly different features here, being carved into the surface of a flat and undulating morainic upland with specific glacial levels (Fig. 1) that show a preferred orientation due to erosional activity of subglacial waters.

Geological and geomorphological mapping provided numerous data on the landforms and geological setting of the channel system and its surroundings (Deneko and Andrzejewski, 2012). It appears that both the oriented convex forms and the channel fills, from the surface to a depth of several metres, are composed of till, which confirms a glacial origin. The northern part of the channel, in the Gronowo area, is consequently assumed to have been eroded by subglacial meltwater. However, the southern part that is located on the opposite side of the ice-marginal valley, in the Piotrkowo area, has a more complex origin. Following the classification by Niewiarowski (1995b), it may be considered a glacial-glaciofluvial landform. Its initial outline was shaped by glacial erosion (ice streams?), whereas its final form was determined by subglacial waters that cut through the lower upland levels. The first subglacial developmental stages of the channel system took place during the Kujawy-Dobrzyń subphase, whereas the subsequent proglacial stages continued during the Krajna-Wąbrzeźno subphase of the last glaciation. The final development of this complex channel, which occurred during the Late Glacial and the beginning of the Holocene, accompanied the gradual degradation of the ice, preserving the lowest channel parts.

\section{RESEARCH METHODS}

\author{
FIELDWORK
}

The geological setting of the study area was thoroughly investigated through numerous drillings with the Eijkelkamp man- ual probe. Geological and geomorphological mapping was carried out to establish the (large) thickness (several metres) and diversity of the biogenic sediments (Figs. 2 and 3). Eventually, cores of undisturbed organic sediments were collected from the Gronowo (denoted as G) and Piotrkowo (denoted as P) sites for laboratory analyses, using a Livingstone probe as modified by Więckowski $(1959,1966)$, for the samples from boreholes GI, GII and PI, and an Ins-torf manual probe for the samples from borehole GV.

\section{POLLEN ANALYSIS}

For pollen analysis, 170 sediment samples, each with a volume of $1 \mathrm{~cm}^{3}$, were collected at a standard $10 \mathrm{~cm}$ resolution (or less if considered necessary or desirable). The sediments were macerated following the standard procedure (Dyakowska, 1959; Berglund and Ralska-Jasiewiczowa, 1986; Sadowska and Chłopek, 2003). Carbonate compounds were removed with $10 \% \mathrm{HCl}$. Afterwards, Lycopodium indicator tablets were added in order to determine the concentration of sporomorphs. Next, humic acids were removed from the material by boiling with $10 \% \mathrm{KOH}$. The content of cellulose compounds was decreased through Erdtman acetolysis. Mineral matter was removed from the sediment with $40 \% \mathrm{HF}$. The pollen analysis was carried out under a light microscope at magnifications of 100x, 200x and 400x. The results were presented using the POLPAL software for Windows (Nalepka and Walanus, 2003; Walanus and Nalepka, 1996; Figs. 4-7). At least 1,000 pollen grains of trees and shrubs (AP) were counted, except for the silty sediments from borehole PI, where - due to the low pollen concentration only up to 200 AP grains could be counted.

\section{PLANT MACRO-REMAINS ANALYSIS}

Plant macro-remains analysis was performed for 12 samples from borehole GII. The material was macerated according to a procedure applied at the W. Szafer Institute of Botany, Polish Academy of Sciences (Velichkevich and Zastawniak, 2006), including boiling of the sediment with $10 \% \mathrm{KOH}$ followed by wet-sieving on a $0.2 \mathrm{~mm}$ sieve. After preparation, the samples were analysed under a stereoscopic microscope. The sorted remains were identified with the use of numerous atlases and keys (Berggren, 1969; Cappers et al., 2006; Velichkevich and Zastawniak, 2006, 2008). The results were depicted in a histogram plotted with the POLPAL software for Windows (Nalepka and Walanus, 2003).

\section{RADIOCARBON DATING}

The radiocarbon age of sediments was determined for eight samples. Sample preparation followed Walanus and Goslar (2009). Four samples were examined with the AMS method in the Poznan Radiocarbon Laboratory, whereas the other four samples were dated with the conventional method in the Radiocarbon Laboratory, Silesian University of Technology at Gliwice (Poland). The ages were calibrated with the OxCal v4.1.7 software (Reimer et al., 2009) to cal BP age (see Appendix $1^{*}$ ).

\section{LOSS ON IGNITION}

The loss of ignition was determined for 89 samples in order to characterize the organic sediments. The samples were 
A

\section{B}

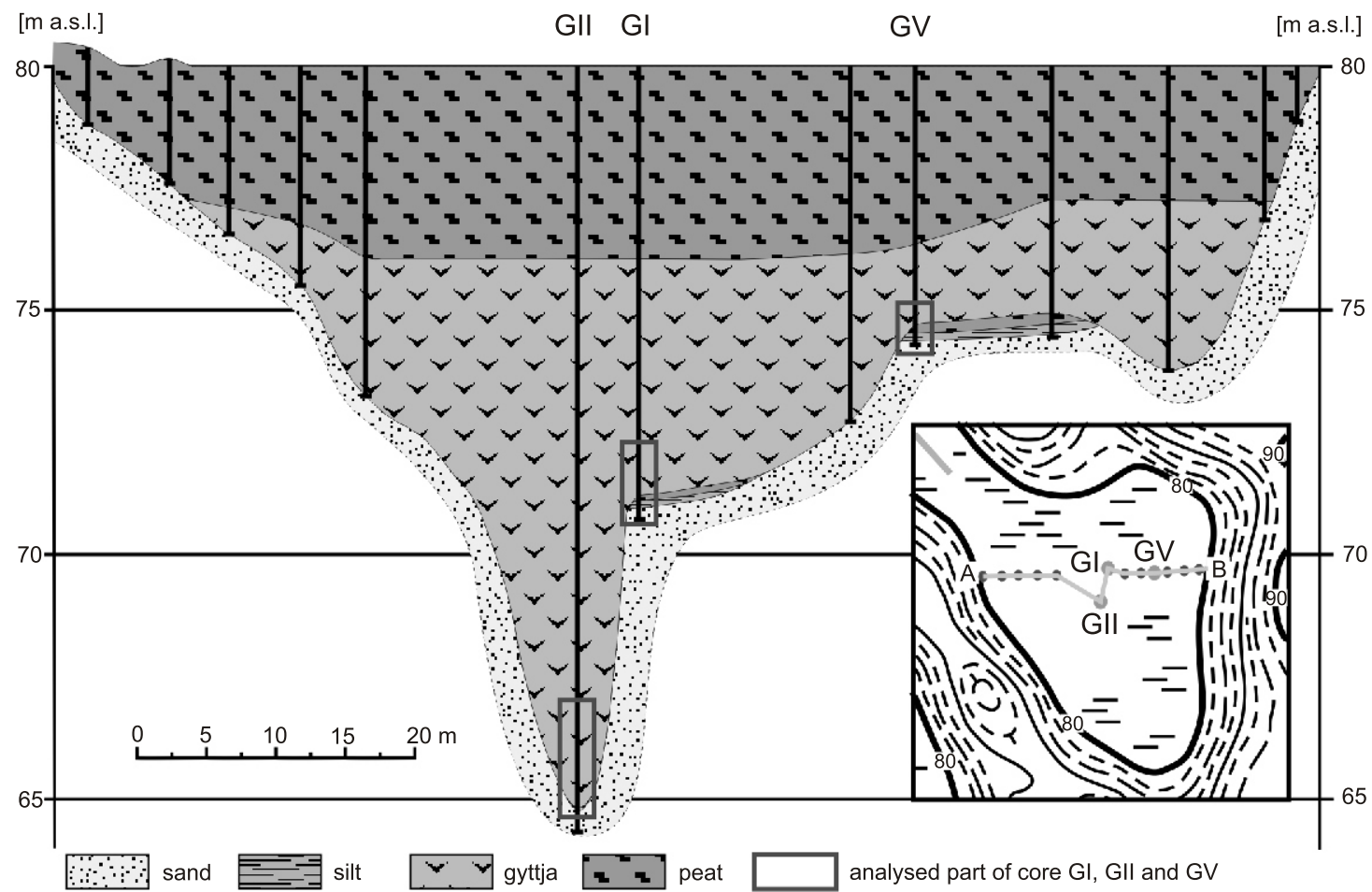

Fig. 2. Cross-section through the Gronowo site

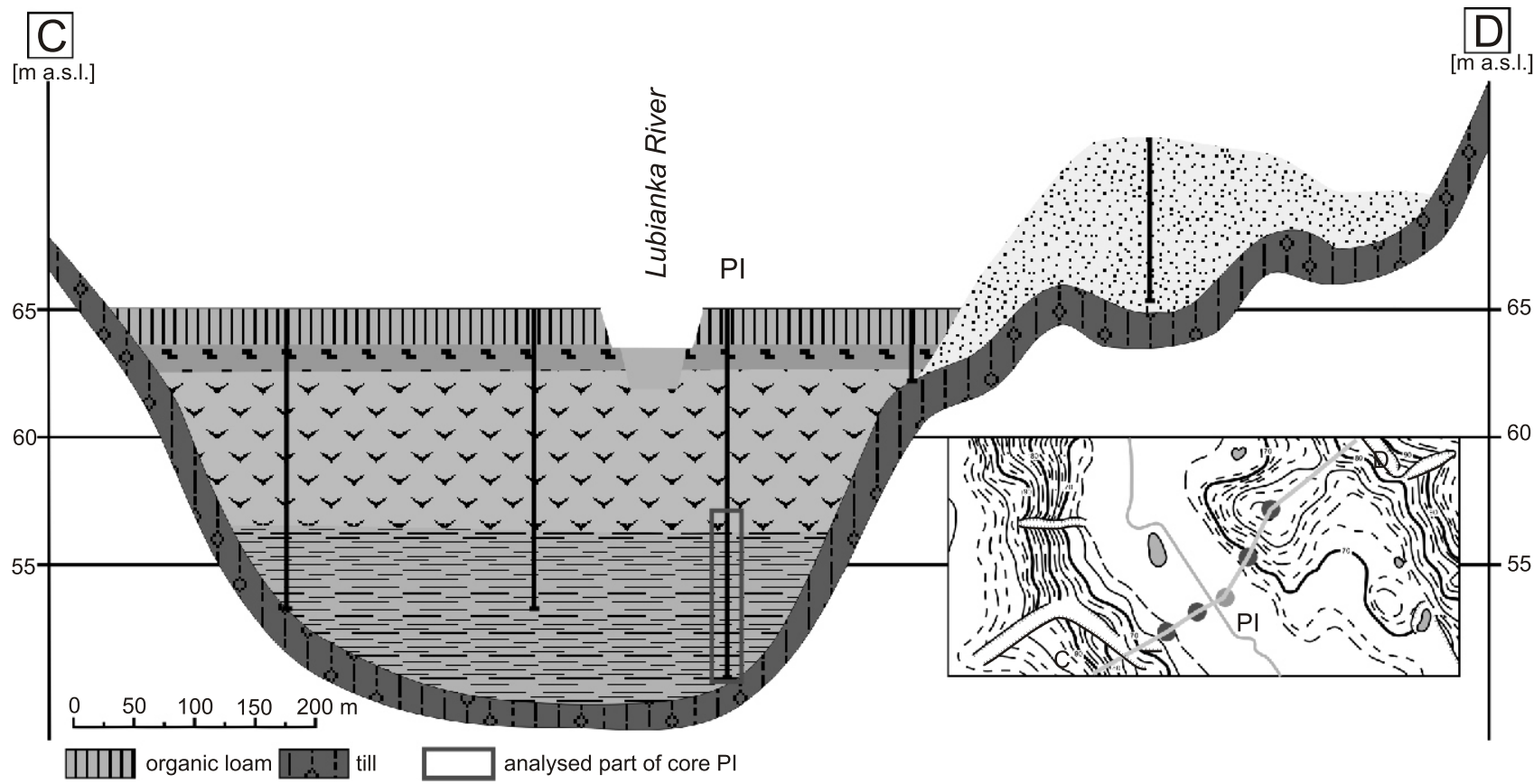

Fig. 3. Cross-section through the Piotrkowo site

Other explanations as in Figure 2 


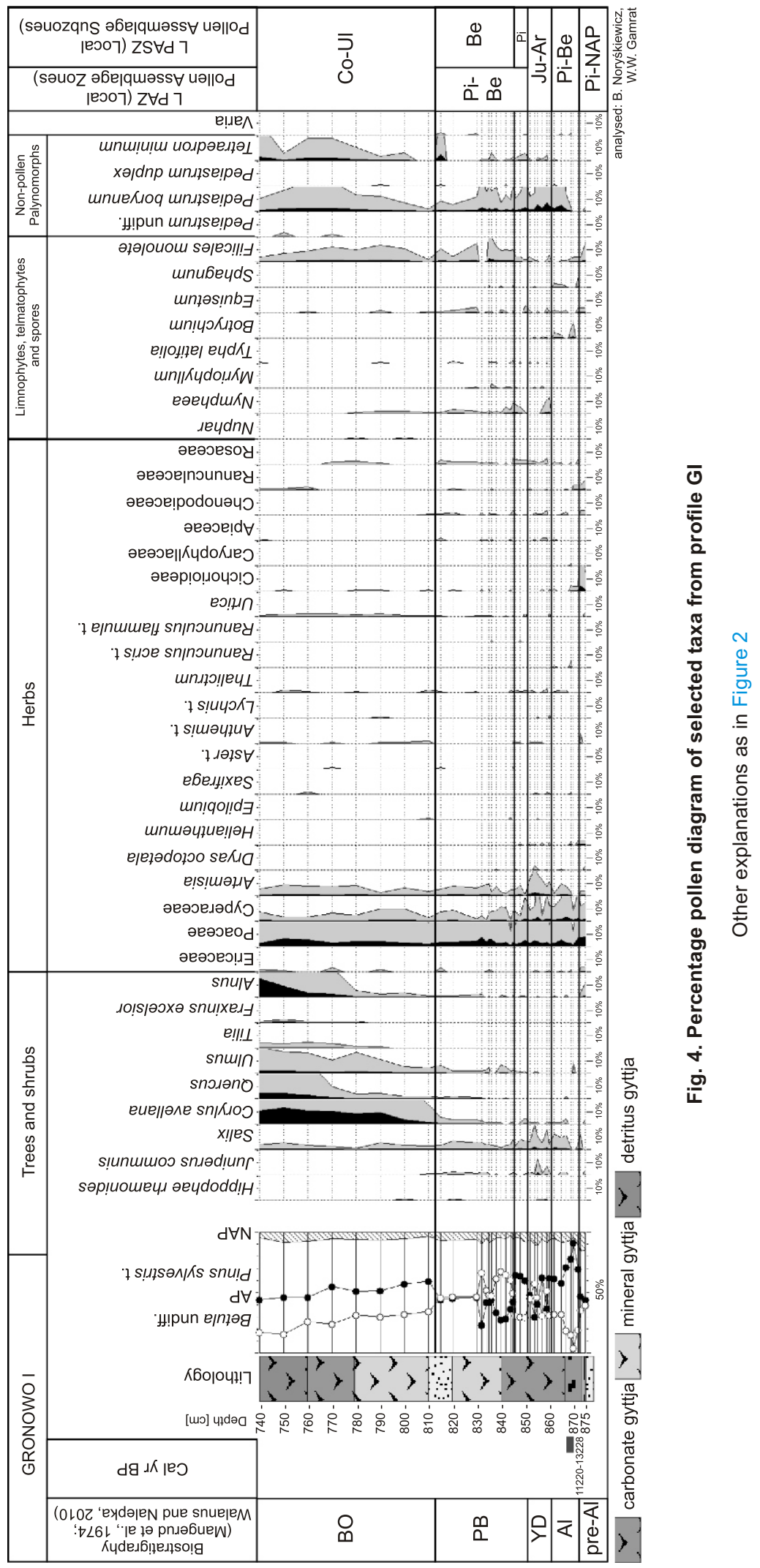




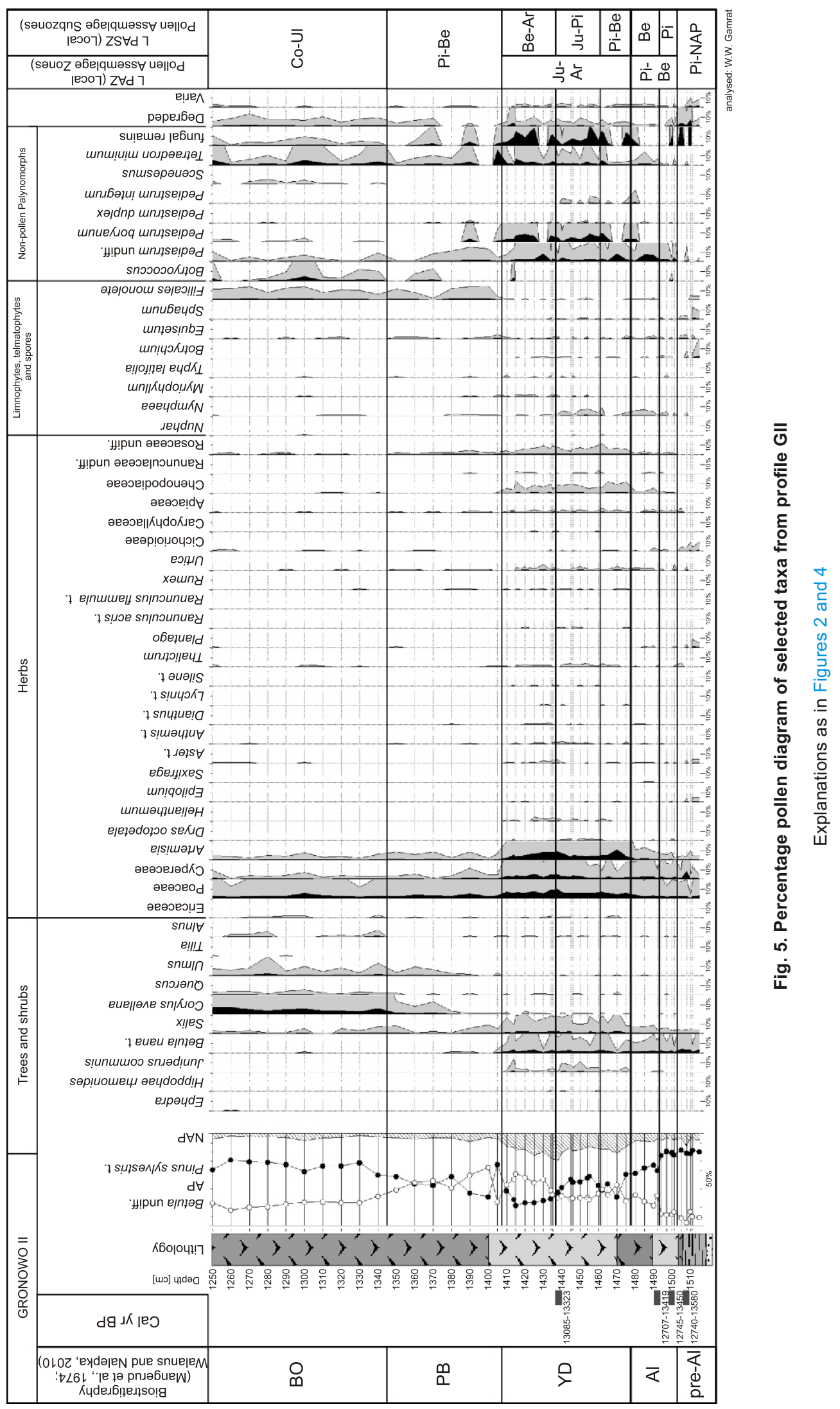




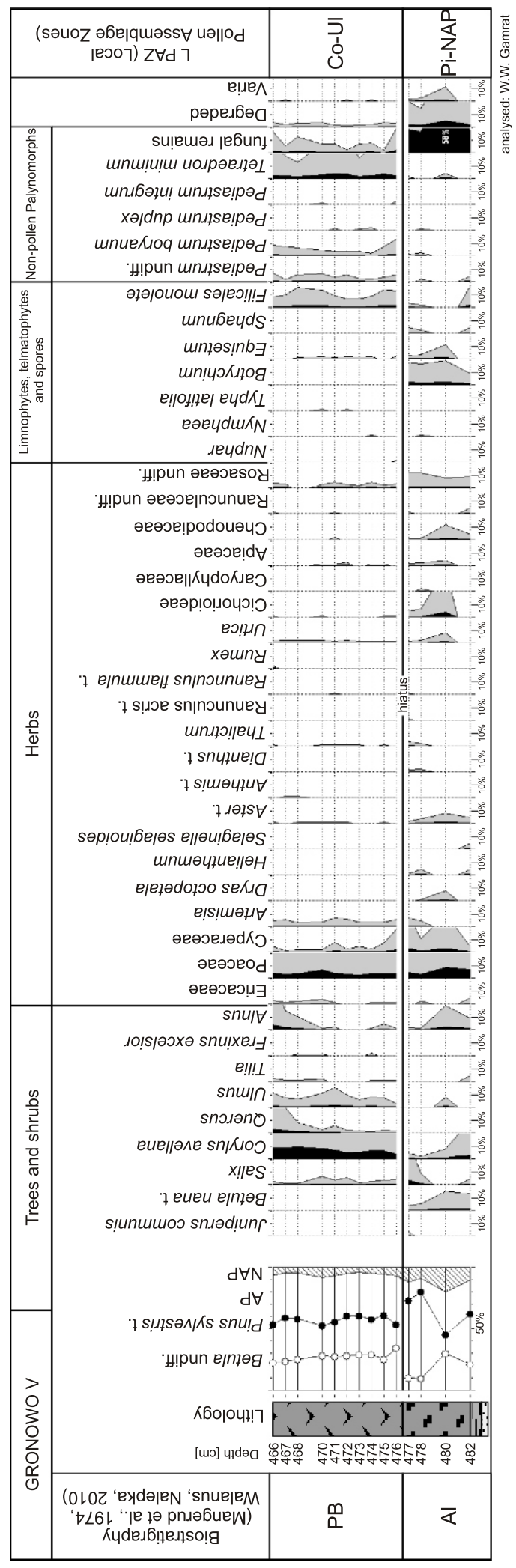

weighed before and after ignition at 105,550 and $920^{\circ} \mathrm{C}$, in order to determine the content of organic matter, carbonate compounds, and non-carbonate mineral residue.

\section{NUMERICAL ANALYSES}

All numerical procedures were carried out with the POLPAL 2004 software package. The results of the pollen analyses were processed using the ConSLink method, rarefaction analysis (RA), analysis of the sample similarity matrix (SSM), and principal component analysis (PCA). This enabled verification of the division into L PAZ and correlation of the various pollen diagrams.

\section{RESULTS}

The results of all analyses are compiled in Appendix 1, together with additional information on the pollen assemblage zones, plant macro-remains, radiocarbon datings, and the changes in lithology. The reconstruction of basins evolution (Figs. 8 and 9) follows the biostratigraphic division of the Late Glacial and the Holocene by Mangerud et al. (1974), calibrated by Walanus and Nalepka (2010). The chronostratigraphy follows that proposed by Litt et al. (2001) for the Late Glacial, and by Starkel et al. (2013) for the Early Holocene.

\section{A. End of the Plenivistulian (before 14,450 cal BP - Litt et al., 2001)}

The oldest organic sediments, represent by grey, locally laminated silts, were found at the Piotrkowo site (zone $\mathrm{P}_{1}$, 1440-890 cm; Appendix 1, Figs. 7 and 9A-C). The pollen spectra allow distinguishing one pollen assemblage zone $\left(\mathrm{P}_{\mathrm{P}}-1\right.$ NAP-Pinus-Betula) with three subzones $\left(\mathrm{P}_{1}-1\right.$ a Pinus, $\mathrm{P}_{1}-1$ Betula and $\mathrm{P}_{1}-1 \mathrm{c}$ NAP-Juniperus). Palynological analysis indicates that the sediments accumulated in a cold phase with a poor plant cover representing a tundra or a steppe-tundra. Such conditions intensified denudation and reworking of older sediments, as evidenced by the presence of numerous sporomorphs of Neogene taxa (such as Pterocarya, Taxodium and Sequoia) and remains of fungi (e.g., Glomus-type) and dinoflagellates (described as "Hystrix" on pollen diagram; Fig. 7).

Changes in the relative amounts of pine, tree-birches and juniper pollen, as well as in the pollen concentration, enabled division into subzones $\mathrm{P}_{\mathrm{I}}-1 \mathrm{a}$ and $\mathrm{P}_{\mathrm{l}}-1 \mathrm{c}$ (Fig. 9B, D), interpreted as cold phases, and subzone $\mathrm{P}_{\mathrm{I}}-1 \mathrm{~b}$ which represents a short phase of relatively higher temperature and humidity (Fig. 9C). In the pollen diagram, this is illustrated by the dominance of Betula (including B. nana) and Salix, accompanied by a decrease in the content of reworked sporomorphs (Fig. 7). The short duration of stable environmental conditions is clearly evidenced by the presence of laminated sediments at a depth of 1198-1205 cm, dated at 18,901-19,363 cal BP (Appendix 1). Considering the age of the sediments and the pollen spectra, which are similar to those from sites in Denmark (de Klerk, 2004; Mortensen et al., 2011), Lithuania (Stančikaitè et al., 2008) and Germany (Litt et al., 1997, 1998, 2003; Litt and Stebich, 1999; Leroy et al., 2000; de Klerk, 2002; de Klerk et al., 2008), this part of the core can be assigned with certainty to the end of the Plenivistulian.

A similar observation was made in Poland by Niewiarowski (1995) for Biskupińskie Lake, with silts dated as $17,700 \pm 220$ BP. Palynological examination of these sediments by Noryśkiewicz (1995a) indicated a cold phase characterized by numerous reworked sporomorphs, including Neogene ones, and by the presence of dinoflagellates (Hystrix), just 


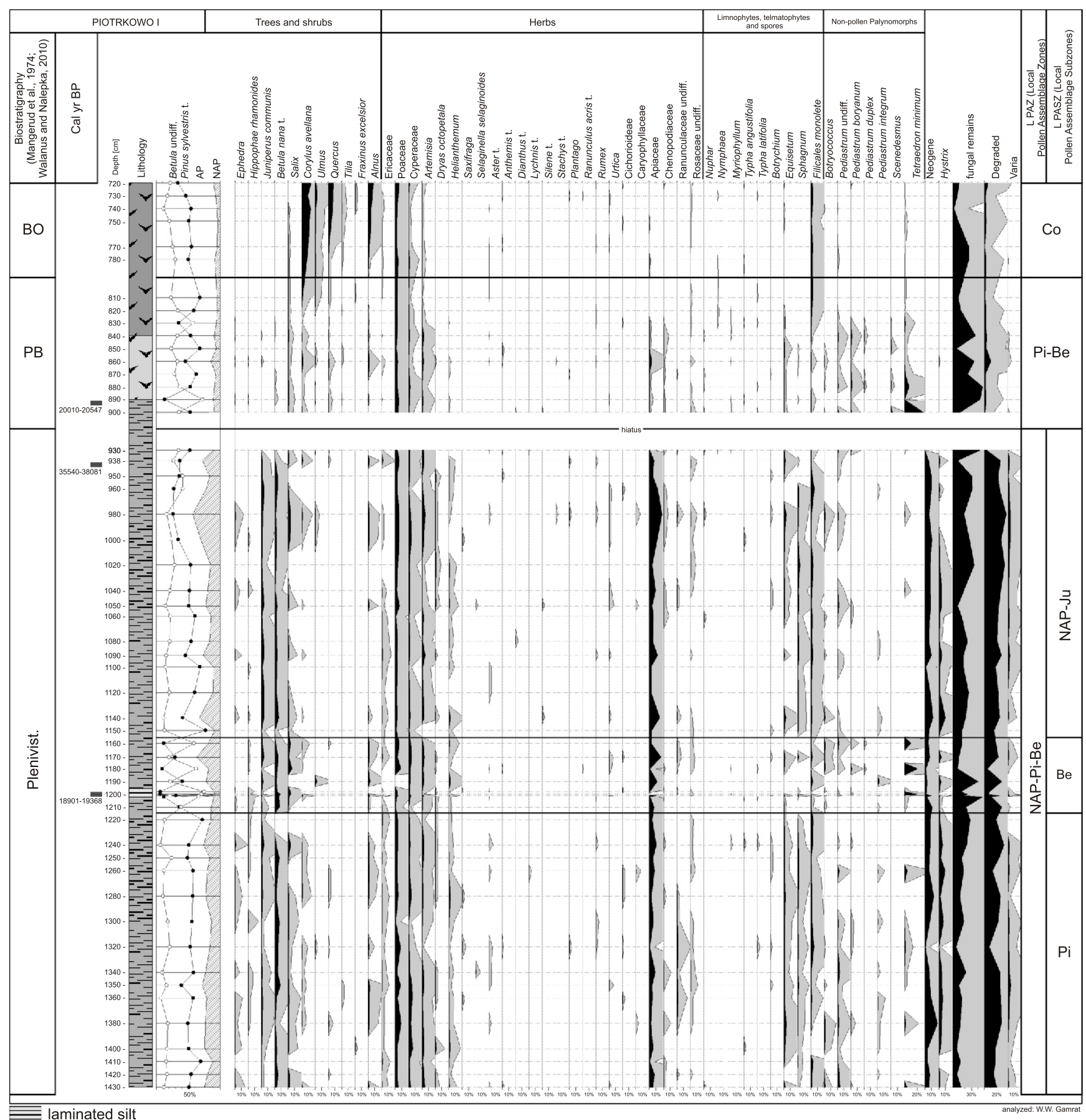

Fig. 7. Percentage pollen diagram of selected taxa from profile PI

Explanations as in Figures 2 and 4

as in profile $\mathrm{PI}$ (Fig. 7). Plenivistulian silts were also described from the area of Miłkowskie Lake (Wacnik, 2009) and the Żabieniec site (Balwierz, 2010).

B. Late Glacial (11,590-13,350 cal BP - Litt et al., 2001)

Late Glacial sediments were identified in three profiles from the Gronowo site, namely GI, GII and GV (Appendix 1). Profile PI does not include deposits of this age (Appendix 1), most likely due to erosion that took place during the further evolution of the Lubianka channel, or due to non-deposition (Fig. 8D).

a. Pre-Allerød (before 13,350 cal BP - Litt et al., 2001)

Pre-Allerød sediments, present as laminae of grey organic silts (several centimetres thick), were found at the Gronowo site (zones $\mathrm{G}_{1}-1$ and $\mathrm{G}_{\|}-1$, and basal part of profile $\mathrm{GV}$, which is de- void of pollen grains; Appendix 1, Figs. 4-6 and 8C). The pollen spectra show a dominance of Pinus, with minor amounts of herbaceous plants and a low concentration of pollen grains.

The sediments may have been accumulated during either the Bölling or the Meiendorf and were therefore assigned roughly to the pre-Allerød, just like was done for numerous other sites in northern Poland (Błaszkiewicz, 2005; Karasiewicz et al., 2014). Sedimentation occurred in an aquatic environment, as indicated by the presence of Characeae, Daphnia and Cristatella mucedo macrofossils in profile GII (depth of $1504-1513 \mathrm{~cm}$; Appendix 1). The initial small shallow-water basin was formed due to melting out of dead-ice blocks, which started during this time-span (Fig. 8B). 


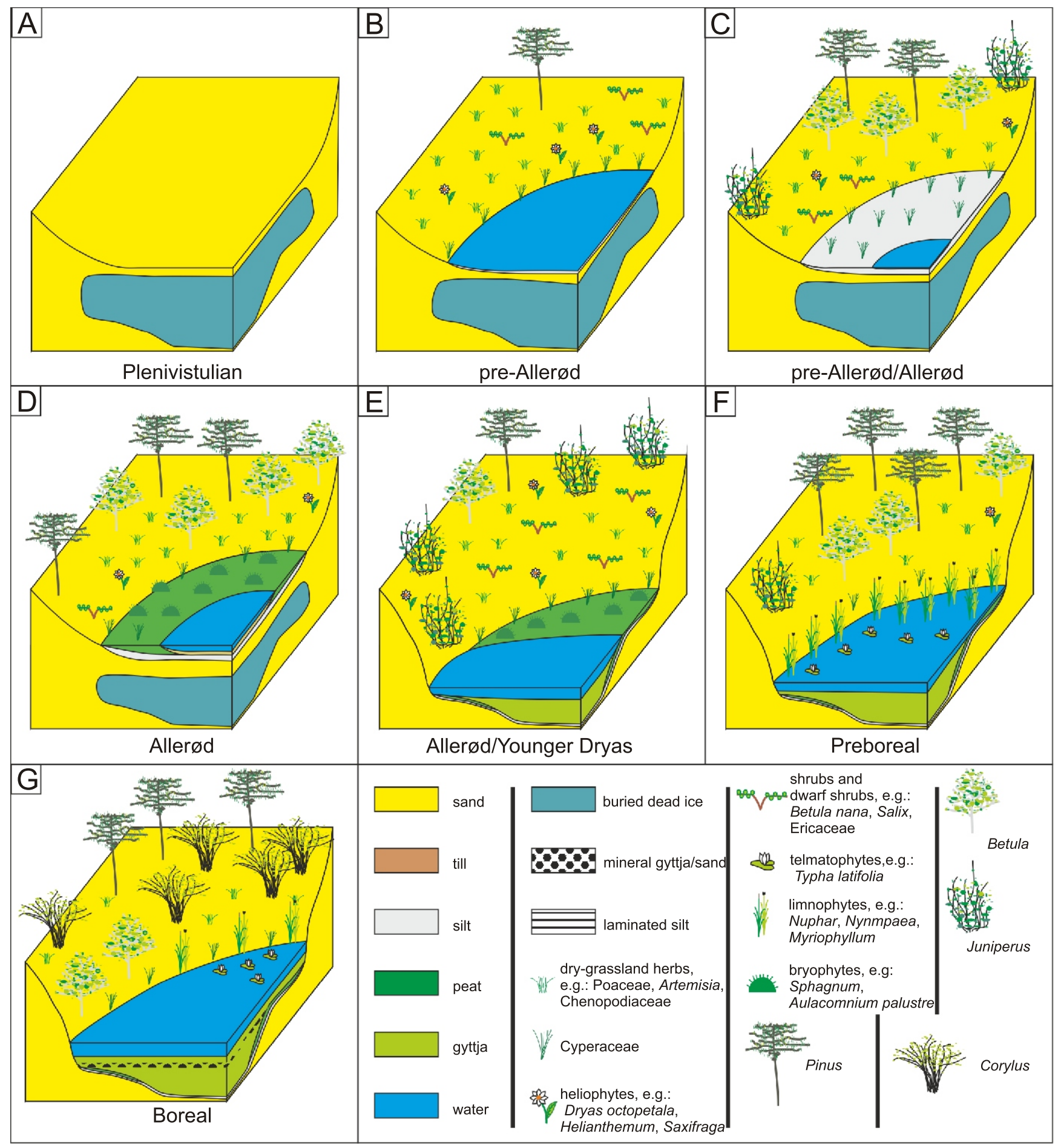

Fig. 8. Schematic development of the Gronowo site

See text for details

b. Allerød (12,680-13,350 cal BP - Litt et al., 2001)

Analysis of the Gronowo pollen grains (zones $\mathrm{G}_{\mathrm{I}}-2, \mathrm{G}_{\|}-2$ and $\mathrm{G}_{\mathrm{V}}-1$; Appendix 1, Figs. 4-6 and 8) shows that the sedimentation took place in this area during the older, "pine" part of the Allerød, when pine and pine-birch forests dominated, locally with steppe and tundra plant communities (including Helianthemum, Artemisia and Dryas octopetala). This age was confirmed by radiocarbon datings (GdS-602, 12,745-13,450 cal BP, and Gd-30,154, 12,707-13,419 cal BP; Appendix 1).
Sediments of this phase show significant variability in lithology and spatial extent (Fig. 8C, D). The central part of the basin was characterized by deposition of mineral and carbonate gyttjas comprising endocarps of Potamogeton and Nymphaea as well as fragments of Characeae and Daphnia $\left(\mathrm{G}_{\|}-2\right.$; Appendix 1), whereas the margins were overgrown by plants that formed peat (spores of Sphagnum in zones $\mathrm{G}_{\mathrm{l}}-2$ and $\mathrm{G}_{\mathrm{V}}-1$; Appendix 1) with Aulacomium palustre as the dominant species (macroscopic identification). 


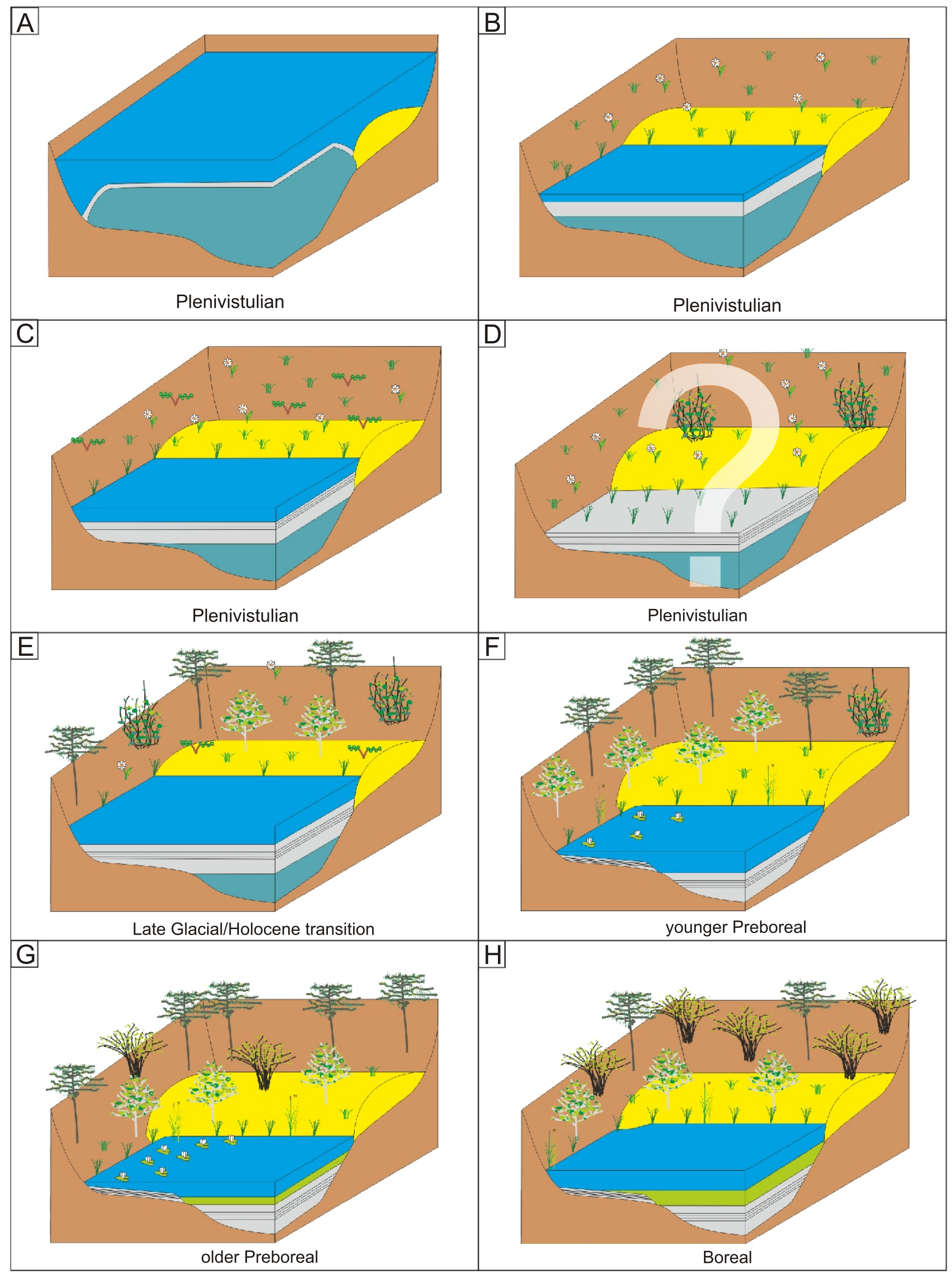

Fig. 9. Schematic development of the Piotrkowo site

Explanations as in Figure 8 
Dating of the GI core from a depth of $868-870 \mathrm{~cm}$ indicates an age of 11,220-13,228 cal BP (Gd-18499; Appendix 1). Due to a large dating error, the precise age of the sediment is not known, but it is definitely Allerød. Climate amelioration resulted in melting of buried dead ice and in paludification of the area. Initially, peat covered the marginal zone of the basin, but thermokarst developed when the basin became ever deeper (Fig. 8D). In the presence of water that did not freeze at the basin bottom during winter, the rate of dead-ice degradation increased and a deep lake originated, in which mineral and carbonate gyttja accumulated. The high rate of this phenomenon is justified by the lack of terrestrial sediments in the central part and by the accumulation of Allerød lacustrine sediments directly on top of the peat in the marginal part of the basin (Fig. 8D).

c. Younger Dryas (11,500 cal BP - Starkel et al., 2013; 11,590-12,680 cal BP - Litt et al., 2001)

Younger Dryas sediments are present in profiles $\mathrm{GI}$ and $\mathrm{GI}$ (Appendix 1, Figs. 4 and 5); the GII profile shows a fairly detailed palynological record, enabling a subdivision into three pollen assemblage subzones $\left(\mathrm{G}_{\|}-3 \mathrm{a}\right.$ Pinus-Betula, $1460-1475 \mathrm{~cm} ; \mathrm{G}_{\|}-3 \mathrm{~b}$ Juniperus-Pinus, $1435-1460 \mathrm{~cm} ; \mathrm{G}_{\|}-3 \mathrm{c}$ Betula-Artemisia, 1405-1435 cm; Fig. 5). This subdivision can be ascribed to phases of climate changes, just like those distinguished for the Younger Dryas sediments at the Witów site near Łęczyca; the various phases, thoroughly described by Wasylikowa (2001), correspond to humidity fluctuations and aeolian processes, as reported by Latałowa (2003b).

Diagram Gll shows the three phases. The first phase $\left(G_{\|}-3 a, 1460-1475 \mathrm{~cm}\right)$, characterized by strong fluctuations in the content of Pinus and Betula and by an increase in the proportion of herbaceous plants (NAP), can be correlated with the initial climate cooling at the Allerød/Younger Dryas boundary (Fig. 8E). The second phase $\left(\mathrm{G}_{\|}-3 \mathrm{~b}, 1435-1460 \mathrm{~cm}\right)$, distinguished on the basis of dominance of Pinus and Juniperus (which is an indicator of a relatively dry climate), can be most likely linked to the cooler part of the Younger Dryas, with July temperatures ranging from 10 to $11^{\circ} \mathrm{C}$ (Isarin and Renssen, 1999). The last phase $\left(\mathrm{G}_{\|}-3 \mathrm{c}, 1405-1435 \mathrm{~cm}\right)$, dominated by Artemisia and Betula, indicates an increase in climate humidity; this phase can be associated with the warmer part of the Younger Dryas, with July temperatures exceeding $13^{\circ} \mathrm{C}$ (Isarin and Bohncke, 1999).

Sediments accumulated during the Younger Dryas show a high content of mineral matter (Madeyska, 1995; Latałowa, 2003b), which was also found in the present study. Younger Dryas sediments are, however, not present in profile GV of the Gronowo basin (Appendix 1, Figs. 6 and 8E). This might be due to the position of the basin's bottom (recorded as the lowermost sediments), which was situated almost $10 \mathrm{~m}$ higher than that of profile GII. The lack of Younger Dryas sediments may therefore result from a temporarily lower water level, as also reported in studies by Niewiarowski (1995a) and other researchers who investigated lakeland areas in Poland.

The radiocarbon age of a sample from a depth of $1439 \mathrm{~cm}$, indicating 13,085-13,323 cal BP (Poz-43480; Appendix 1), is clearly too old if compared with the results provided by pollen analysis results. This may be ascribed to the hard-water effect (Walanus and Goslar, 2009). 2013)

C. Early Holocene $(9,600-11,500$ cal BP - Starkel et al.,

Early Holocene sediments, which are present in all profiles (GI, GII, GV and PI; Appendix 1 and Figs. 4-7), indicate continuous lake sedimentation under variable depositional conditions, in both time and space. a. Preboreal $(10,200-11,500$ cal BP - Starkel et al., 2013)

Preboreal sediments are described here from profiles $\mathrm{GI}$, GII and PI (Appendix 1 and Figs. 4-7, 8F, 9F, G). At the Gronowo site, the Preboreal is characterized by a decrease in the NAP content and by a rapid increase in the pollen-grain concentration in profiles GI (Andrzejewski et al., 2009) and GII (Appendix 1). The pollen spectra are first dominated by Pinus and later by Betula. They also show a decrease and disappearance of earlier continuous curves of heliophilous shrubs and herbaceous plants (Juniperus, Betula nana, Dryas octopetala, and Helianthemum), as well as the appearance of continuous curves of Corylus, Quercus and Ulmus (Figs. 4 and 5). Such changes in the pollen spectra are typical for sites of lakeland areas in Poland (Ralska-Jasiewiczowa et al., 1998; Latałowa, 2003a).

Preboreal sediments contain considerable amounts of mineral matter. This is well-expressed especially in profile GI (Appendix 1), parts of which $(810-820 \mathrm{~cm})$ comprise sands and show a strong decrease in pollen-grain concentration, but no increase in the content of broken sporomorphs (Fig. 4). Profile GII (Appendix 1) shows this, too, but also contains mineral gyttjas. This may result from local changes in the natural environment, most likely linked to fluctuations in water level and formation of a lake terrace along the lake margins.

At the Piotrkowo site, first typical lacustrine sediments (mineral and carbonate gyttjas) developed during the Preboreal, as shown by zone $\mathrm{P}_{1}-2 \quad(790-900 \mathrm{~cm})$ which overlies the Plenivistulian silts (Appendix 1 and Fig. 7). Just like in profiles GII and $\mathrm{GI}$, the Preboreal pollen spectra indicate a variable dominance of Pinus and Betula, whereas heliophilous plants disappeared, becoming replaced by more demanding taxa, such as Corylus, Quercus and Ulmus (Fig. 7).

The lithological diversity of the sediments suggests that the dead ice did not melt away completely before the beginning of the Holocene (Fig. 9E) and that the part of the Lubianka channel under study was then incorporated in the Drwęca River system. This resulted in lowering of the erosion base and consequently partial efficient drainage of meltwater and redeposition of older sediments (Fig. 9F). Subsequently, the conditions in the basin began to stabilize, as indicated by the sedimentary development initially with mineral (clayey) gyttja and later with carbonate gyttja (Fig. 9G). According to the pollen spectra, all the changes continued and the basin was already surrounded by dense pine-birch and birch-pine forests.

b. Boreal (9,600-10,200 cal BP - Starkel et al., 2013)

Boreal pollen spectra were found in all profiles (Appendix 1 and Figs. 4-7). They are characterized by a high content (at least several percent) of Corylus and by a gradual increase in Quercus, Ulmus, Tilia and Fraxinus. Locally, Alnus was frequent; it most likely replaced other taxa in habitats of greater humidity. At the Piotrkowo site, carbonate gyttja and lacustrine chalk (over $80 \%$ of carbonate compounds; Figs. 7 and $9 \mathrm{H}$ ) were deposited, whereas accumulation of carbonate gyttja (ca. $40 \%$ of carbonate compounds) and mineral gyttja occurred at the Gronowo site. It is worth mentioning here that profile GV contains carbonate gyttja that directly overlies the Alleröd peat (Fig. 8G). This may indicate a rise in the water level of the lake.

\section{COMPARISON OF THE BASINS DEVELOPMENTS - DISCUSSION}

The research results indicate an asynchronous development of the two lakes in the two basins under study. At the 
Gronowo site, lake sedimentation started during the older, "pine" part of the Allerød, and was preceded by a short-term occurrence of a peat bog, organic deposits of which can be now found at the base of the lacustrine sediments. In the case of the Piotrkowo site, the beginning of lake sedimentation was dated as Preboreal. However, at the end of the Plenivistulian and the beginning of the Late Glacial, a small and shallow ice-dammed lake, already existed in this part of the channel. Its glaciolacustrine deposits are present at the base (grey silts, $980-1440 \mathrm{~cm}$ ). This indicates a hiatus of $5 \mathrm{ka}$ between the glaciolacustrine and non-glacigenic lacustrine accumulations.

An asynchronous origin of lakes has been commonly reported for postglacial areas of the central European lowlands. In northern Poland, three main lake generations, namely the pre-Allerød, Allerød and Early Holocene ones, can be distinguished (Błaszkiewicz, 2005, 2007, 2011b). In Germany, most ice-covered lakes of the Last Glacial Maximum were formed in the Bölling-Alleröd complex sensu lato (Kaiser et al., 2012), but individual lakes were also found to have initiated during the Preboreal (Homann et al., 2002). Błaszkiewicz (2005, 2011b) described the asynchronous development of lakes in postglacial areas as a common result of differences in the melting away of dead-ice blocks, buried within the initial depressions.

The reasons for such a difference in the moment of appearance are differences in the thickness and lithological characteristics of the mineral layer overlying the dead-ice blocks (Niewiarowski, 1989; Böse, 1995; Błaszkiewicz, 2005, 2011) as well as thermo-isolation provided by the peat cover (Nowaczyk, 1994; Błaszkiewicz, 2005). The key factor affecting the course of thawing during the Late Glacial is, however, the presence of water and its drainage potential. Water-involving thermokarst processes have been discussed extensively in literature, also in the context of observations in presently glaciated areas influenced by modern periglacial processes (Jones et al., 2011; Niu et al., 2011; Jaworski and Niewiarowski, 2012; Grosse et al., 2013; Jaworski and Chutkowski, 2015; Jaworski, 2017) . The crucial event for dead-ice block melting is the first incident of non-freezing of water at the lake bottom during winter, so that it can fill a basin in the immediate surroundings (Błaszkiewicz et al., 2015). The constant presence and thermal effect of water intensifies thawing processes so that dead-ice blocks, still present at the bottom of a depression after several thousands of years, then melt away within a few tens of years. Therefore, the local hydrogeological conditions and the development of a local drainage network in the thus-formed depressions played a very important role in postglacial thawing.

Through the present study, this aspect of lake basin evolution can be detailed. In the Gronowo area, the local morphology of the subglacial channel hindered the water outflow during the initial thawing. Paludification of the depression on top of the buried ice resulted in a short phase of peat-bog development, followed by the development of a basin that rapidly deepened by thermokarst, at the beginning of the Allerød. Rather soon, already in the Middle Allerød, the depression became completely separated from the ice and turned into a $15.2 \mathrm{~m}$ deep lake. At the Piotrkowo site, in contrast, the local morphology and the close vicinity of the Drwęca River, descending to lower levels, allowed the depression to be drained by a local stream throughout the Late Glacial. The buried dead ice in this area was consequently better protected against fast melting. The presence of Plenivistulian glaciolacustrine sediments, which reached a thickness of $5 \mathrm{~m}$, was also of great importance for the preservation of dead-ice blocks. When, the climate promptly became warmer at the beginning of the Holocene, the dead ice rapidly melted away, causing the replacement of this basin by deep lake water $(9.8 \mathrm{~m})$. The through-flow lake became relatively quickly filled with lacustrine and deltaic sediments and, at a final stage, with peats.

The presence of dead-ice blocks in the depression at Piotrkowo until the beginning of the Holocene strongly supports the conclusion that islands of permafrost could persist in this area throughout the Late Glacial. It cannot be excluded that the higher content of mineral particles in the Preboreal lacustrine sediments may result from degradation of permafrost, which must have triggered full water circulation in the immediate surroundings of the basin. Similar conclusions on permafrost and the island-like pattern of preserved dead ice until the beginning of the Holocene were drawn for eastern Pomerania (Błaszkiewicz, 2011b; Van Loon et al., 2012; Błaszkiewicz et al., 2015).

\section{CONCLUSIONS}

The Gronowo and Piotrkowo sites are located at a short distance from each other, within a widespread system of subglacial channels cutting through the Drwęca ice-marginal valley. Investigation of these sites indicates that they both underwent a multi-stage development, including the appearance and disappearance of a lake. The following conclusions can be drawn with respect to the development of the lake basins and their immediate surroundings.

1. The lakes appeared almost 3,000 years after each other, viz. during the Allerød at the Gronowo site and during the Preboreal at Piotrkowo. This is proven by both radiocarbon dating and analysis of the pollen and macro-plant remains.

2. The glaciolacustrine sediments are separated from non-glacigenic lacustrine sediments by a hiatus spanning over 5,000 years (Plenivistulian/Preboreal) at the Piotrkowo site.

3. The dead ice and/or permafrost at both sites melted away at different rates. At Gronowo, the degradation of the buried ice was initially slow and resulted in paludification of the basin margin as well as in the development of a peat bog. Deepening of the basin and thermokarst conditions facilitated the melting of the buried dead ice, as recorded in the Allerød gyttjas. At the Piotrkowo site, the dead ice melted away faster and later (Preboreal), which must be ascribed to the local surface drainage conditions that allowed water discharge throughout the Late Glacial. At the beginning of the Preboreal, when the climate ameliorated rapidly, the channel was quickly separated from the ice and a through-lake stream was formed. The presence of a thick cover of glaciolacustrine sediments, which had accumulated at the site during the Plenivistulian, also played an important role in the preservation of buried dead ice during the Late Glacial.

4. The occurrence of dead-ice blocks at the Piotrkowo site still at the beginning of the Holocene indicates that islands of permafrost could persist in this area throughout the Late Glacial.

These conclusions make clear how important are local hydrogeological conditions for the evolution of lake postglacial basins.

Acknowledgements. We thank Prof. A. van Loon and an anonymous reviewer for helpful comments on earlier drafts. The research was financed by the Ministry of Science and Higher Education, grant No. N N306 722840, entitled "Morphogenesis and 
evolution of the natural environment in the northern part of the Lubianka River channel and its surroundings (Dobrzyń Plateau) on the basis of palaeobotanical and geomorphological studies", as well as the Science and Research Funds for 2015-2016, allocated to a co-financed international project, Contract No.
$3500 /$ ICLEA/15/2016/0. This study is a contribution to the Virtual Institute of Integrated Climate and Landscape Evolution (ICLEA) of the Helmholz Association.

\section{REFERENCES}

Andrzejewski, L., 1994. Evolution of the fluvial system of the lower Vistula valley in the Late Vistulian and Holocene on the base of selected valley of its tributaries (in Polish with English summary). Wydawnictwo UMK, Toruń.

Andrzejewski, L., Gamrat, W.W., Noryśkiewicz, B., 2009. Zarys ewolucji środowiska przyrodniczego okolic Gronowa w okresie późnego glacjału i holocenu w świetle badań palinologicznych (in Polish). In: Badania podstawowe i aplikacyjne w naukach geograficznych (ed. L. Kasprzak): 235-240. Wydawnictwo UAM, Poznań.

Balwierz, Z., 2010. Analiza pyłkowa osadów torfowiska Żabieniec. In: Torfowisko Żabieniec. Warunki naturalne, rozwój i zapis zmian paleoekologicznych w jego osadach (eds. J. Twardy, S. Żurek and J. Forysiak): 179-188. Wydawnictwo Naukowe Bogucki, Poznań

Benn, D.I., Evans, D.J.A., 1998. Glaciers and Glaciations. Arnold, London.

Berggren, G., 1969. Atlas of Seeds and Small Fruits of Northwest-European Plant Species with Morphological Descriptions. Part 2. Cyperaceae. Swedish Natural Sciences Research Council, Stockholm.

Berglund, B.E., Ralska-Jasiewiczowa, M., 1986. Pollen analysis and pollen diagrams. In: Handbook of Holocene Palaeoecology and Palaeohydrology (ed. B.E. Berglund): 455-484. John Wiley \& Sons Ltd., Chichester.

Błaszkiewicz, M., 1998. Dolina Wierzycy, jej geneza oraz rozwój w późnym plejstocenie i wczesnym holocenie (in Polish). Dokumentacja Geograficzna, 10.

Błaszkiewicz, M., 2005. Późnoglacjalna i wczesnoholoceńska ewolucja obniżeń jeziornych na Pojezierzu Kociewskim (wschodnia część Pomorza) (in Polish). Prace Geograficzne, 201. Wydawnictwo Naukowe IGiZP, Warszawa.

Błaszkiewicz, M., 2007. Geneza i ewolucja mis jeziornych na młodoglacjalnym obszarze Polski - wybrane problemy (in Polish). Studia Limnologia et Telematologica, 1: 5-16.

Błaszkiewicz, M., 2011a. Stanowisko 5. Gronowo. Geomorfologia w rejonie stanowiska Gronowo (in Polish). In: Człowiek i jego wpływ na środowisko przyrodnicze w przeszłości i czasach historycznych. V Polska Konferencja Paleobotaniki Czwartorzędu (eds. P. Hulisz, M.T. Karasiewicz and A.M. Noryśkiewicz): 113-114. Państwowy Instytut Geologiczny, Warszawa.

Błaszkiewicz, M., 2011b. Timing of the final disappearance of permafrost in the central European Lowland, as reconstructed from the evolution of lakes in N Poland. Geological Quarterly, 55 (4) 361-374.

Błaszkiewicz, M., Kordowski, J., 2009. Objaśnienia do Szczegółowej Mapy Geologicznej Polski w skali 1:50 000, ark. Kowalewo Pomorskie, numer 326 (in Polish). Państwowy Instytut Geologiczny, Warszawa.

Błaszkiewicz, M., Brademan, B., Brauer, A., Brykała, D., Degórski, M., Froehlich, W., Gierszewski, P., Hirsch, F., Kaczmarek, H., Kordowski, J., Kramkowski, M., Krzymińska, J., Lamparski, P., Lutyńska, M., Mirosław-Grabowska, J., Nicolay, A., Noryśkiewicz, A., Noryśkiewicz, B., Obremska, M., Ott, F., Raab, A., Raab, T., Schneider, A., Schwab, M., Słowiński, M., Tyszkowski, S., Wulf, S., Zawiska, I., 2013. Introduction to ICLEA fieldtrips - Stara Kiszewa 2013. 2nd Annual
ICLEA Workshop 2013: Dynamics of climate and landscape evolution of cultural landscape in the Northern Central European Lowlands since the last ice age: 53-66, Potsdam.

Błaszkiewicz, M., Piotrowski, J., Brauer, A., Gierszewski, P., Kordowski, J., Kramkowski, M., Lamparski, P., Lorenz, S., Noryśkiewicz, A., Ott, F., Słowiński, M., Tyszkowski, S., 2015. Climatic and morphological controls on diachronous postglacial lake and river valley evolution in the area of Last Glaciation, northern Poland. Quaternary Science Reviews, 119: 13-27.

Böse, M., 1995. Problems of dead ice and ground ice in the central part of the North European plain. Quaternary International, 28 123-125.

Cappers, R.T.J., Bekker, R.M., Jans, J.E.A., 2006. Digital Seed Atlas of the Netherlands. Bakhuis/Groningen University Library, Groningen.

De Klerk, P., 2002. Changing vegetation patterns in the Endinger Bruch area (Vorpommern, NE Germany) during the Weichselian Lateglacial and Early Holocene. Review of Palaeobotany and Palynology, 119: 275-309.

De Klerk, P., 2004. Confusing concepts in Lateglacial startigraphy and geochronology: origin, consequences, conclusions (with special emphasis on the type locality Bøllings $\varnothing$ ). Review of Palaeobotany and Palynology, 129: 265-298.

De Klerk, P., Janke, W., Kühn, P., Theuerkrauf, M., 2008. Environmental impact of the Laacher See eruption at a large distance from the volcano: integrated palaeoecological studies from Vorpommern (NE Germany). Palaeogeography, Palaeoclimatology, Palaeoecology, 270: 196-214.

Deneko, P., Andrzejewski, L., $2012 . \quad$ Morfogeneza ukierunkowanych form $\mathrm{w}$ obrębie północnego fragmentu subglacjalnej rynny rzeki Lubianki (Wysoczyzna Dobrzyńska) (in Polish). Przestrzeń w badaniach geograficznych (eds. K. Fortuniak et al.): 37-45. Wydawnictwo UŁ, Łódź

Dyakowska, J., 1959. Podręcznik analizy pyłkowej (in Polish). Metody i problemy. Wyd. Geol., Warszawa.

Dzierżek, J., 2009. Paleografia wybranych obszarów Polski w czasie ostatniego zlodowacenia (in Polish). Acta Geographica Lodziensia, 95: 1-112.

Galon, R., 1983. On the origin of subglacial channels. Studies in Quaternary Geomorphology (eds. D.J. Briggs and R.S. Waters) 85-95. International Symposia Series, Cambridge.

Gamrat, W.W., Andrzejewski, L., Krześlak, I., 2014. Postglacjalne zmiany środowiska przyrodniczego na Wysoczyźnie Dobrzyńskiej zapisane w profilu osadów biogenicznych w Piotrkowie (in Polish). Landform Analysis, 25: 3-11.

Grosse, G., Jones, B., Arp, C., 2013. Thermokarst lakes, drainage, and drained basins. In: Treatise on Geomorphology (ed. J.F. Shroder): 325-353. Academic Press, San Diego.

Homann, M., Merkt, J., Müller, H., 2002. Sedimentologische und pollenanalytische Untersuchungen einiger mecklenburgischer Seen - ein West-Ost-Transekt. Greifswalder Geographische Arbeiten, 26: 35-38

Isarin, R.F.B., Bohncke, S.J.P., 1999. Mean July temperatures during the Younger Dryas in northwestern and central Europe as inferred from climate indicator plant species. Quaternary Research, 51: 158-173. 
Isarin, R.F.B., Renssen, H., 1999. Reconstructing and modeling late Weichselian climates: the Younger Dryas in Europe as a case study. Earth-Science Reviews, 48:1-38.

Jaworski, T., 2017. The morphology of peat bog surfaces on Hermansenoya, NW Svalbard. Polar Science, 11: 83-95.

Jaworski, T., Chutkowski, K., 2015. Genesis, morphology, age and distribution of cryogenic mounds on Kaffiøyra and Hermansenøya, Northwest Svalbard. Permafrost and Periglacial Processes, 26: 304-320.

Jaworski, T., Niewiarowski, W., 2012. Frost peat mounds on Hermansenøya (Oscar II Land, NW Svalbard): their genesis, age and terminology. Boreas, 41: 660-672.

Jones, B.M., Grosse, G., Arp, C.D., Jones, M.C., Walter-Anthony, K.M., Romanowsky, V.E., 2011. Modern thermokarst lake dynamics in the continuous permafrost zone, northern Seward Pennisula, Alaska. Journal of Geophysical Research. Biogeosciences, 116, G00M03.

Kaiser, K., 2001. Die spätpleistozöne bis frühholozöne Beckenentwicklung in Mecklenburg-Vorpommern. Greifswalder Geographische Arbeiten, 24: 1-208.

Kaiser, K., Hilgers, A., Schlaak, N., Jankowski, M., Kühn, P., Bussemer, S., Przegiętka, K., 2009. Palaeopedological marker horizons in northern central Europe: characteristics of Lateglacial Usselo and Finow soils. Boreas, 38: 591-609.

Kaiser, K., Lorenz, S., Germer, S., Juschus, O., Küster, M., Libra, J., Bens, O., Hüttl, R.F., 2012. Late Quaternary evolution of rivers, lakes and peatland in northeast Germany reflecting past climatic and human impact - an overview. E\&G Quaternary Science Journal, 61: 103-132.

Karasiewicz, M.T., Hulisz, P., Noryśkiewicz, A.M., Krześlak, I. Świtoniak, M., 2014. The record of hydroclimatic changes in the sediments of a kettle-hole in a young glacial landscape (north-central Poland). Quaternary International, 328-329: 264-276.

Kot, R., 2015. The point bonitation method for evaluating geodiversity: a guide with examples (Polish Lowland). Geografiska Annaler, Series A: Physical Geography, 97 375-393.

Kozarski, S., 1967. Origin of the subglacial channels in the North Polish and North German Plain. Bulletin de la Société des Sciences et des Lettres de Poznań. Série B: Sciences Mathématiques et Naturelles, 20: 21-36.

Latałowa, M., 2003a. Holocen (in Polish). In: Palinologia (eds. S. Dybova-Jachowicz and A. Sadowska): 273-307. Wydawnictwo IB PAN, Kraków.

Latałowa, M., 2003b. Późny glacjał (in Polish). In: Palinologia (eds S. Dybova-Jachowicz and A., Sadowska): 266-272. Wydawnictwo IB PAN, Kraków.

Leroy, S.A.G., Zotlitschka, B., Negendank, J.F.W., Seret, G. 2000. Palynological analyses in the laminated sediment of Lake Holzmaar (Eifel, Germany); duration of Lateglacial and Preboreal biozones. Boreas, 29: 52-71.

Litt, T., Stebich, M., 1999. Bio- and chronostratigraphy of the lateglacial in the Eifel region, Germany. Quaternary International, 61: 5-16.

Litt, T., Früchtl, M., Kubisz, B., Stebich, M., 1997. Palaeobotanical Investigations. 7th International Symposium on Paleolimnology. Excurision B: Laacher See and Eifel maar lakes. Heiligkreuztal 25-29. Germany.

Litt, T., Stebich, M., Brauer, A., 1998. Bio- and chronostratigraphy of the Lateglacial in the Eifel region based on varved sediments. Mediterranean Lacustrine Records. 3rd Workshop of the European Lake Drilling Programme ELDP. Ptolemais: 82-88.

Litt, T., Brauer, A., Goslar, T., Merkt, J., Bałaga, K., Müller, H., Ralska-Jasiewiczowa, M., Stebich, M., Negendank, J.F.W., 2001. Correlation and synchronisation of Lateglacial continental sequences in northern central Europe based on annually laminated lacustrine sediments. Quaternary Science Reviews. 20: $1233-1249$
Litt, T., Schmicke, H.-U., Kromer, B., 2003. Environmental response to climate and volcanic events in central Europe during the Weichselian Lateglacial. Quaternary Science Reviews, 22: 7-32.

Madeyska, T., 1995. Roślinność Polski u schyłku części ostatniego zlodowacenia (in Polish). Przegląd Geograficzny, 43: 595-599.

Mangerud, J., Andersen, S.T., Berglund, B.E., Donner, J.J., 1974. Quaternary stratigraphy of Norden, a proposal for terminology and classification. Boreas, 3: 109-128.

Marks, L., 1996. Rola martwego lodu w kształtowaniu mis jeziornych obecnych pojezierzy (in Polish). Acta Geographica Lodziensia, 71: 181-193.

Molewski, P., 1999. The Gopło subglacial channel (tunnel valley) the problem of its origin and participation in meltwater outflow during the Vistulian glaciation (in Polish with English summary). Studia Societatis Scientiarum Torunensis, Geographia et Geologia, 10: 1-172.

Morrtensen, M.F., Birks, H.H., Christensen, Ch., Holm, J., NoeNygaard, N., Odgaard, B.V., Olsen, J., Rasmussen, K.L., 2011. Lateglacial vegetation development in Denmark - New evidence based on macrofossil and pollen from Slotseng, a small-scale site in southern Jutland. Quaternary Science Reviews, 30: 2534-2550.

Nalepka, D., Walanus, A., 2003. Data processing in pollen analysis. Acta Palaeobotanica, 43: 125-134.

Niewiarowski, W., 1959. Formy polodowcowe i typy deglacjacji na Wysoczyźnie Chełmińskiej (in Polish). Studia Societatis Scientiarum Torunensis, 4: 1-170.

Niewiarowski, W., 1968. Morfologia i rozwój pradoliny i doliny dolnej Drwęcy (in Polish). Studia Societatis Scientiarum Torunensis, 6: 1-131.

Niewiarowski, W., 1988. Levels in subglacial channels and their significance in determining the channel origin and evolution. Geographia Polonica, 55: 114-127.

Niewiarowski, W., 1989. Wahania poziomu jezior w późnym glacjale i w holocenie na przykładzie jezior Pojezierza Brodnickiego (in Polish). Studia i materiały oceanologiczne, $\mathbf{5 6}$ 277-288.

Niewiarowski, W., 1995a. Wahania poziomu wody w jeziorze biskupińskim i ich przyczyny (in Polish). In: Zarys zmian środowiska geograficznego okolic Biskupina pod wpływem czynników naturalnych i antropogenicznych w późnym glacjale i holocenie (ed. W. Niewiarowski): 215-234. Wydawnictwo Turpress, Toruń

Niewiarowski, W., 1995b. Diagnostic features of subglacial channels of glacial and glacio-glaciofluvial origin, exampled by channels of the Chełmno-Dobrzyń and the eastern Gniezno lakelands. Quaestiones Geographicae, Special Issue, 4: 225-231.

Niewiarowski, W., 2003. Pleni- and late Vistulian glacial lakes, their sediments and landforms: a case study from the young glacial landscape of northern Poland. Prace Geograficzne, 189: 61-85.

Nitz, B., 1984. Grundzüge der Beckenentwicklung im mitteleuropäischen Tiefland - Modell einer Sediment- und Reliefgenese. Peterrmanns Geographische Mitteilungen, 128: 133-141.

Nitz, B., Schirrmeister, L., Klessen, R., 1995. Spätglazial-altholozöne Landshaftsgeschichte auf dem nördlichen Barnim - zum Beckenentwicklung im nordostdeutschen Tiefland. Peterrmanns Geographische Mitteilungen, 139 143-158.

Niu, F., Lin, Z., Liu, H., Lu, J., 2011. Characteristics of thermokarst lakes and their influence on permafrost in Qinghaie Tibet Plateau. Geomorphology, 132: 222-233.

Noryśkiewicz, B., 1995. Zmiany szaty roślinnej okolic jeziora Biskupińskiego w późnym glacjale i holocenie pod wpływem czynników naturalnych i antropogenicznych (in Polish). In: Zarys zmian środowiska geograficznego okolic Biskupina pod wpływem czynników naturalnych i antropogenicznych w późnym glacjale i holocenie (ed. W. Niewiarowski): 147-179. Wydawnictwo Turpress, Toruń. 
Nowaczyk, B., 1994. Wiek jezior i problemy zaniku brył martwego lodu na przykładzie sandru Brdy w okolicy Charzykowy (in Polish). Acta Universitatis Nicolai Copernici, Geografia, 27: 97-110.

Pachur, H.J., Röper, H.P., 1987. Zur Paläolimnologie Berlin Seen. Berliner Geographische Abhandlungen, 44.

Pasierbski, M., 1979. Remarks on the genesis of subglacial channels in northern Poland. Eiszeitalter und Gegenwart, 29: 185-200.

Piotrowski, J., Tylmann, K., Narloch, W., Wysota, W., Damsgaard, A., Egholm, D.L., Larsen, N.K., 2014. A soft-bed system under the Skandinavian Ice Sheet: mosaic of stable and deforming spots. In: Abstrackt from 31st Nordic Geological Winter Meeting: 1, Lund.

Ralska-Jasiewiczowa, M., Goslar, T., Madeyska, T., Starkel, L., 1998. Lake Gościąż, central Poland. A monographic study. Part 1. Wydawnictwo IB PAN, Kraków.

Reimer, P.J., Baillie, M.G.L., Bard, E., Bayliss, A., Beck, J.W., Blackwell, P.G., Bronk Ramsey, C., Buck, C.E., Burr, G.S., Edwards, R.L., Friedrich, M., Grotes, P.M., Guilderson, T.P., Hajdas, I., Heaton, T.J., Hogg, A.G., Hughen, K.A., Kaiser, K.F., Kromer, B., McCormac, F.G., Manning, S.W., Reimer, R.W., Richards, D.A., Southon, J.R., Talamo, S., Turney, C.S.M., van der Plicht, J., Weyhenmeyer, C.E., 2009. Intcal09 and Marine09 radiocarbon age calibration curves, 0-50000 years cal BP. Radiocarbon, 51: 1111-1150.

Sadowska, A., Chłopek, K., 2003. Metody terenowe i laboratoryjne (in Polish). In: Palinologia (eds. S. Dybova-Jachowicz and A. Sadowska): 72-82. Wydawnictwo IB PAN, Kraków.

Słowiński, M., Błaszkiewicz, M., Brauer, A., Noryśkiewicz, B., Ott, F., Tyszkowski, S., 2014. The role of melting dead ice on landscape transformation in the early Holocene in Tuchola Pinewoods, North Poland. Quaternary International, 388: 64-75.

Stančikaitè, M., Šinkūnas, P., Šeirienè, V., Kisielinè, D., 2008. Patterns and chronology of the Lateglacial environmental development at Pamerkiai and Kašučiai, Lithuania. Quaternary Science Reviews, 27: 127-147.

Starkel, L., Michczyńska, D.J., Krąpiec, M., Margielewski, W., Nalepka, D., Pazdur, A., 2013. Progress in the holocene chrono-climatostratigraphy of polish territory. Geochronometria, 40: 1-21.

Van Loon, A., Błaszkiewicz, M., Degórski, M., 2012. The role of permafrost in shaping the Late Glacial relief of northern Poland. Netherlands Journal of Geosciences, 91: 223-231.

Velichkevich, F.Yu., Zastawniak, E., 2006. Atlas of the Pleistocene vascular plant macrofossils of Central and Eastern Europe. Part 1 - Pteridophytes and monocotyledons. Wydawnictwo IB PAN, Kraków.

Velichkevich, F.Yu., Zastawniak, E., 2008. Atlas of the Pleistocene vascular plant macrofossils of Central and Eastern Europe. Part 2 - Herbaceous dicotyledons. Wydawnictwo IB PAN, Kraków.

Wacnik, A., 2009. Vegetation development in the Lake Miłkowski area, north-eastern Poland, from the Plenivistulian to the late Holocene. Acta Palaeobotanica, 49: 287-335.

Walanus, A., Goslar, T., 2009. Radiocarbon dating (in Polish with English summary). Wydawnictwo AGH, Kraków.

Walanus, A., Nalepka, D., 1996. Program POLPAL - palinologiczna baza danych, Instrukcja obsługi (in Polish). Wydawnictwo IB PAN, Kraków.

Walanus, A., Nalepka, D., 2010. Calibration of Mangerud's boundaries. Radiocarbon, 52: 1639-1644.

Wasylikowa, K., 2001. Przemiany roślinności jako odbicie procesów wydmotwórczych i osadniczych w młodszym dryasie i holocenie na stanowisku archeologicznym w Witowie koło Łęczycy (in Polish). Prace i Materiały Muzeum Archeologicznego i Etnograficznego w Łodzi, seria archeologiczna, 41: 43-80.

Więckowski, K., 1959. Pierwsze próby z sondą rdzeniową do pobierania monolitów osadów dennych jezior (in Polish). Przegląd Geograficzny, 31: 361-366.

Więckowski, K., 1966. Osady denne Jeziora Mikołajewskiego (in Polish). Prace Geograficzne IG PAN, 57.

Więckowski, K., 1993. Dotychczasowny stan rozpoznania osadów dennych jezior "Na Jazach” - cechy makroskopowe (in Polish). In: Jezioro Gościąż - stań badań nad osadami dennymi i środowiskiem współczesnym (ed. M. Ralska-Jasiewiczowa): 77-92. Polish Botanical Studies Guidebook Series, 8. 